\title{
Learning Strategies Instruction in CLIL Textbooks and Teacher-Authored Materials: A Qualitative Study
}

\author{
Marcella Menegale \\ Department of Linguistics and Comparative Cultural Studies \\ Ca' Foscari University of Venice \\ Dorsoduro 1075, 30123, Venezia, Italy
}

Tel: 393-473-239-010 E-mail: menegale@unive.it

Received: February 26, 2020

doi:10.5296/ijl.v12i2.16537
Accepted: March 12, 2020 Published: March 23, 2020

URL: https://doi.org/10.5296/ijl.v12i2.16537

\begin{abstract}
The aim of the study here presented was to understand to what extent CLIL materials are oriented towards the development of learning strategies (cognitive, metacognitive and socio-affective strategies). This was done through the analysis of teaching materials of different content subject areas for primary and secondary school levels. A qualitative approach was adopted to compare learning units taken from commercial CLIL textbooks alongside self-authored materials created by CLIL teachers for their classes. A set of informative data was gathered to detect which strategies were most developed, whether any relevant differences between the materials analysed could be spotted, and whether strategy instruction was implicit or explicit. Main findings show that the types of strategies found in CLIL materials are very similar to those applied in second and foreign language learning environments and, although no significant differences have been spotted between textbooks and self-authored materials as to strategy instruction, the data has provided some interesting insights which deserve further exploration. It is hoped that the work will shed some light on practices of effective integration of learning strategies in CLIL teaching.
\end{abstract}

Keywords: Learning strategy, CLIL, Teaching material, Textbook

\section{Introduction}

Content and Language Integrated Learning (CLIL) is a bilingual approach where subject matter is learnt through an additional language (foreign or second language). Although it was devised with a primary focus on foreign language learning - in the ' $90 \mathrm{~s}$, in response to 
European policies advocating an increase in students' foreign language proficiency and the promotion of plurilingualism - it was soon clear that "CLIL is more than just another method of language learning. CLIL has implications for the learning process as a whole and is as such an innovative way of looking at (language) education" (Van de Craen et al., 2007, p. 75). This means that different dimensions need reconsideration: the way the language is learnt (and taught), the way the content is learnt (and taught) and the way the learning process is regulated (and supported).

CLIL teachers, aware of cognitivist and constructivist theories, will understand the importance of getting their students to carry out actions directed at the development of autonomy, at regulating their learning process (e.g., planning their learning, monitoring understanding and production, assessing achievements) and at controlling specific language acquisition mechanisms, which may otherwise remain insufficiently activated (e.g., noticing or focussing-on-form, automatizating processes, restructuring linguistic representations). If it is true that the CLIL approach can be adopted with students of any language level and age, it is also true that those who cannot use the target language "to take notes from teacher-presentations, plan and revise their writing, interpret graphs or report the outcomes of group work" will likely attain "reduced levels" of subject content knowledge (Clegg, 2007, p. 126). It is here that learning strategies have an important role to play. The importance of helping students be more strategic in their study, that is, to be able to successfully cope with a new and challenging way of learning, is something that cannot be disregarded. Similarly, the teaching resources that can support learner strategy development should be taken into consideration. Nevertheless, reflections and studies about how learning strategies could be integrated into CLIL programmes and to what extent teaching materials can support this development are rather scarce in the CLIL literature. The study presented here hopes to contribute to shedding some light on this critical issue.

\section{Models of Learning Strategies Instruction}

Strategy instruction aimed at supporting learner efficacy in the learning process has a long history in education, mainly in the psychological field. Fortunately, the extensive research in the field both in first and second language learning contexts has led to the development of different models of language learning strategy instruction (for a review see Cohen \& Macaro, 2007; Oxford, 2011), which represent an important background for advancing the state of the art of strategy instruction in the CLIL field too.

In the specific field of CLIL research, studies on strategies and strategic instruction are still limited (among recent papers, Castellano Risco, 2019; Macaro, 2018; Macaro et al., 2019; Menegale, 2018, 2019a; Psaltou-Joycey et al., 2014; Ruiz de Zarobe \& Zenotz, 2018), "even though [they] are an integral part of the curricular elements that help students to learn" (Ruiz de Zarobe \& Zenotz, 2015, p. 319). Reflecting on the characteristics of a CLIL curriculum, and informed by the taxonomies formerly proposed by other scholars in relation to bilingual programmes like CLIL (i.e., Chamot \& O’Malley, 1994; Coonan, 2012; Macaro, 2018; Navés et al., 2002; Wolff, 2010), a copious strategy repertoire can be outlined which include, for example: strategies for reading comprehension (Ruiz de Zanobe \& Zenotz, 2015; Macaro, 
2018); strategies for preparing and structure writing (Papaja, 2014); communication strategies to overcome linguistic difficulties encountered when trying to communicate in a foreign language with a reduced interlanguage system (García Mayo \& Lázaro Ibarrola, 2015; Martínez-Adrián et al., 2019); vocabulary-related strategies, namely, inferring, networking, working with dictionaries (Castellano Risco, 2019; Eldridge et al., 2010; Macaro et al., 2019); strategies to favour learning transfer (cf. Menegale, 2019b). As CLIL is considered as a more significant and authentic learning environment compared to foreign language learning classrooms, great interest in comparing learning strategies in CLIL and in mainstream EFL contexts has recently emerged, highlighting some interesting findings: Castellano Risco (2019) found that, compared to their counterparts in EFL classrooms, CLIL learners made more use of some vocabulary strategies such as use of English-language media, analysis of affixes and roots and connection with synonyms and antonyms, while they made significantly less use of word lists and written repetition strategies; Psaltou-Joycey et al. (2014) noticed that CLIL learners tended to use a wider range of strategies than their non-CLIL peers, especially fluency-oriented strategies, focusing on pronunciation or intonation; Moore (2011) reported that CLIL learners showed greater engagement through more cooperative turns, thus providing mutual interactive, linguistic and affective support. However, the research in the field is not extensive enough, so what is drawn is "only a partial picture" (Yang, 2018, p. 49).

Although the importance of helping students become more strategic learners is unquestioned, how to do it has been long debated. O' Malley and Chamot (1990, p. 152) addressed some ways to teach strategies: "integrated" strategy instruction (where strategies are carried out as part of the activity itself and "embedded" in the curriculum) versus "separate" strategy instruction (where strategies are overtly discussed, detached from the learning of the subject matter), and "direct" strategy instruction (where strategies are explicitly named and explained, alongside their being practised) versus "implicit" strategy instruction (where students are asked to apply a strategy without being told why). An interesting study by Hattie et al. (1996, cited in $\mathrm{Gu}, 2019$, p. 28) carried out a meta-analysis of 51 studies dealing with strategy instruction experimentations and came to the conclusion that, in order to have a real effect on learning, strategy instruction has to possess three main characteristics: be situated in context, use domain-specific tasks, and involve a high degree of learner metacognitive awareness. These results confirm what other researchers have already stated (i.e., Brown et al., 1983), namely, that implicit strategy instruction, although proving to be effective in improving the learner's performance in the task where the trained strategy is employed, does not lead to the development of a strategic competence which allows the learner to autonomously transfer the taught strategy to other learning tasks and contexts. Direct instruction is said to be the only way for learners to gain deep awareness of their thinking processes, be able to automatize them and to transfer them to other contexts. Given these findings, it has been decided here to focus on models of learning strategy instruction which possess the three characteristics outlined in Hattie et al. (1996).

Of particular relevance to CLIL is the Cognitive Academic Language Learning Approach (CALLA) (Chamot \& O'Malley, 1994) developed in the United States to meet the academic needs of English as a second language (ESL) students in American schools. The CALLA 
design is rooted in a cognitive model of learning (the use of certain strategies becomes meaningful for the learner providing that they are consistent with how the student thinks and learns) and in constructivist and sociocultural theories (learning new information requires mental processing which involves the use of strategies directed at understanding the information, linking it with already existing knowledge and expanding it, relying also on collaboration with others).

Table 1. Learning strategies classification in the CALLA model (adapted from Chamot \& O’Malley, 1994, pp. 62-63)

\begin{tabular}{|c|c|}
\hline Metacognitive strategies & \\
\hline \multicolumn{2}{|l|}{ Planning: } \\
\hline - self-management & plan how to study, arrange the conditions to help one learn. \\
\hline - organisation: & find the main ideas of a text, skim, plan how to carry out a task. \\
\hline - selective attention: & $\begin{array}{l}\text { listen/read selectively; focus on key words, linguistic markers, } \\
\text { specific information, scan. }\end{array}$ \\
\hline - monitoring: & $\begin{array}{l}\text { think while listening/reading/speaking/writing to check one's } \\
\text { comprehension or production. }\end{array}$ \\
\hline - self-assessment & reflect on what has being done and learnt \\
\hline \multicolumn{2}{|l|}{ Cognitive strategies } \\
\hline - using resources & use materials, such as dictionaries, textbooks, etc. \\
\hline - grouping & classify words/concepts, also using graphic organisers \\
\hline - taking notes & $\begin{array}{l}\text { write down key words/concepts in abbreviated verbal/graphic } \\
\text { form }\end{array}$ \\
\hline - using prior knowledge & use what you know, make analogies \\
\hline - summarising & make a mental/oral/written summary of main information \\
\hline - using imagery & using mental/real pictures to understand/learn new information \\
\hline - making inferences & guess from the context and predict upcoming information \\
\hline - inductions/deductions & make/use a rule to understand a concept or complete a task \\
\hline - auditory representation & replay mentally a word, phrase or piece of information \\
\hline \multicolumn{2}{|l|}{ Socio-affective strategies } \\
\hline - asking for clarification & get additional explanation from the teacher or other expert \\
\hline - cooperating & working with peers to complete a task, get feedback \\
\hline - self-talk & reduce anxiety by improving one's sense of competence \\
\hline
\end{tabular}

According to Chamot and O’Malley (1994, p. 10), the CALLA model consists of three components: "topics from the major content subjects, the development of academic language skills, and explicit instruction in learning strategies for both content and language acquisition". So as in CLIL, in CALLA the starting point is subject goals and related learning tasks, and the strategies are meant to help the learners successfully accomplish the learning tasks by overcoming the difficulties derived from having to deal with new complex subject matter and academic language in a second language. In particular, learners use metacognitive strategies to control and use their learning processes more effectively, use cognitive strategies to actively engage in knowledge structuring and organization, and use socio-affective strategies to know how to interact efficiently with others (teachers, peers, 
experts, family, friends, etc.). Table 1 (above) reports the classification of learning strategies adopted by the CALLA model.

Following a top-down approach to explicit learning strategy instruction, CALLA proposes a five-stage sequence where control gradually shifts from the teacher to the students: (1) preparation (the teacher selects goals, identifies appropriate tasks, anticipates learning problems, activates students' background knowledge and strategies, identifies strategies to teach), (2) presentation (the teacher presents new strategies connected with the learning of new concepts and language, and exemplifies the strategies by presenting them in meaningful and diversified contexts), 3) practice (the students are guided in the use of the new strategies and asked to discuss their efforts in applying the strategies during the learning activities), 4) evaluation (the students increase their metacognitive awareness of what they have achieved and assess their learning) and 5) expansion (the students are encouraged to transfer the strategies learnt to other tasks and subjects).

A second approach to learning strategy instruction considered here is Butler's (2002) Strategic Content Learning (SCL). This model was devised to boost learner self-regulation across the curriculum, so it refers to general education and not specifically to language learning. The theoretical framework underpinning SCL is the same as the CALLA model, as both $\mathrm{Gu}(2019)$ and Harris (2019) point out. However, what differentiates SCL from CALLA is that the former is a bottom-up approach to learning strategy instruction, with teacher and students working together from the very beginning of the process to identify useful strategies and apply them in tasks. According to Butler (2002), if it is the teacher, not the student, who decides alone what strategies are needed to accomplish a task, the student will not get access to the full range of cognitive activities central to self-regulation. During SCL instruction, the teacher: 1) helps students identify cues that define task demands and elicits discussion about what procedures and strategies they think could be helpful in carrying out the task, 2) supports students in reflecting on their learning while working through the task, to articulate their task approach strategies in their own words, thereby favouring abstract generalised understandings based on their experiences with the task, and 3) assists students in self-assessing the effectiveness of their actions during learning, their success on the task, and their perceptions of control and competence.

As both CALLA (a top-down approach) and SCL (a bottom-up approach) entail contextualised and task-specific help, with embedded opportunities for development of metacognitive (strategy) awareness, they have been identified as fundamental groundwork for this study, which aimed to understand to what extent learning strategies are trained and developed with CLIL students through teaching materials.

\section{Teaching Materials for CLIL}

The importance of materials for the success of CLIL programmes has frequently been stressed in the literature. However, lack of commercial CLIL textbooks and their claimed inadequacy (when they do exist) seem widely acknowledged among experts. Ball (2018, p. 222) reports that the dearth of "availability or practicality of CLIL materials has often been documented throughout Europe, together with the absence of clear-cut guidelines for the 
oftentimes daunting task of original material preparation". Materials can either be incorporated from authentic sources or adapted from existing materials, or originally designed to fit the needs of CLIL learners across the diversity of CLIL contexts. Whatever their nature, if we accept what has been stated at the beginning of this contribution, namely that "CLIL has implications for the learning process as a whole" (Van de Craen et al., 2007, p. 75), we expect teaching materials to address learning holistically, thus targeting all its dimensions: learning of subject content and of the target language as well as regulation of the underpinning learning processes. Materials should therefore aim at developing content objectives, language objectives and learning to learn objectives.

The scarcity of ready-made CLIL materials seems to be one of the big issues for CLIL teachers. Many scholars stress teachers' difficulties in finding suitable textbooks for their CLIL programmes and remark the huge amount of time required to adapt or create ad hoc materials (Benegas, 2012; Bovellan, 2014; Bonnet, 2012; Coonan \& Ricci Garotti, 2019; Mehisto, 2008; Navés, 2009). According to Ball (2018, p. 224), this indicates that "CLIL, due to its bottom-up development and subsequent organic nature, has been characterized so far by what the British call a DIY approach (do it yourself). Teachers in CLIL-oriented schools have been obliged to practice DIY, or adapt materials already produced for the L1 curriculum". From a teacher development point of view, this is certainly a good opportunity; however, it is unquestionable that this process of text adaptation is massively time-consuming. Furthermore, it may require specific types of skills which not all CLIL teachers have (Coonan, 2007).

That said, two different types of materials will be considered below. The focus of this paper is not the evaluation of existing CLIL materials (regarding, for example, input variety or appropriateness, attractiveness or authenticity), but rather to detect in their design the opportunities for learning to learn. In particular, the materials will be analysed according to whether they are commercially produced (CLIL textbooks) or developed by the teachers themselves (CLIL DIY (do it yourself) materials). The target language considered is English, being the most taught foreign language in CLIL programmes, in Italy as well as around the world.

\subsection{CLIL Textbooks}

While the market for English language teaching coursebooks and resources provides an extremely extensive range of materials that varies according to learners' ages, topics of interest, language levels, favourite learning styles etc., available ready-made CLIL materials are very limited and, sometimes, not even completely adequate from the methodological, linguistic and subject matter point of view. López-Medina (2016, p. 165) reports on some major textbook shortcomings identified by CLIL experts, among which, insufficient scaffolding in terms of the language support that students need in the subject matter - which could be provided as supplementary resources of the textbooks in the form of posters, booklets, or in the textbook itself alongside the task -, inadequate attention to the cultural dimension (one of the 4Cs in Coyle's model, 2005), low attractiveness, detachment from learners' interests, etc.. Tomlinson (2012) also stresses that the production of textbooks is mostly project-based, instead of addressing the content subject curriculum comprehensively. 
In contrast with other studies where the focus has been on how textbooks deal with content or language learning in CLIL (for a review, see Benegas, 2017; López-Medina, 2016; Martín del Pozo \& Rascón Estébanez, 2015; Möller, 2017), the present investigation aims at exploring the materials from the point of view of learning strategy development. The literature on learning strategies in the field of second and foreign language learning indicate the potential that coursebooks have in integrating strategy instruction into the curriculum. Teachers can find out what strategies are promoted, albeit implicitly, by looking at the activities proposed in the coursebook: thus, an activity like "Read the following text and underline the names of the three cities mentioned" implicitly promotes the strategy of selective attention by means of the scanning reading technique. As Psaltou-Joycey (2019, p. 174) states, the recognition of "the strategy promoted implicitly in a coursebook is a good starting point" for language learning strategy instruction because, "by ensuring they are then made explicit to the learners, teachers help them become aware of the learning process and act more independently". Examining widely adopted EFL coursebooks in Greek schools (Psaltou-Joycey, 2014), she found that the most frequent strategies supported at primary grades $\left(1^{\text {st }}-4^{\text {th }}\right.$ grades, ages $\left.7-10\right)$ were guessing intelligently, using resources (i.e., supplementary books, dictionaries etc.), translating, repeating, rote memorization, asking for help and cooperating with others. "Understandably, at this stage the priority is to help pupils not to panic when they encounter unfamiliar language in reading material" (Psaltou-Joycey, 2019, p. 175). This is vital in CLIL contexts as well. In general, beginners should be instructed on processes which can be more easily controlled, like vocabulary memorization (O' Dell, 1997) and reading comprehension (Harris et al., 2001; Macaro, 2018), as such processes allow thinking time to reflect on the strategy to use (in contrast, for example, to listening comprehension, where thinking time to activate strategic processes is reduced).

Again, Psaltou-Joycey (2019) underlined the importance of teaching vocabulary in meaningful contexts, citing evidence from psycholinguistics. She found that rote memorization strategies gave room to more complex strategies at higher levels $\left(5^{\text {th }}\right.$ and $6^{\text {th }}$ grades, ages 11-12) like grouping of vocabulary items in semantic mapping. Activities promoting elaboration of prior knowledge appeared only in grade $6^{\text {th }}$ (age 12), in contradiction with the fact that the use of background knowledge should be elicited from the earlier stages so as to sustain guessing and deduction. Similarly, a lack of affective strategies in primary grade coursebooks was found, notwithstanding their role in helping students cope with anxiety in a context of foreign language learning. At lower secondary education level (ages 13-15), the EFL coursebook analysis found some cases of explicit instruction aimed at developing students' linguistic awareness through learn-how-to-learn activities. The most frequent strategies observed were guessing from context, paraphrasing and using synonyms, semantic mapping, recognition and use of formula and patterns, use of pictures, diagrams, graphs and titles for making inferences, making cultural comparison/association, taking notes when reading listening and writing, and summarising (first attempt found at 2 nd grade, age 14). As for metacognitive strategies, the study reported the presence of self-assessment, planning for writing and monitoring production while, as to socio-affective strategies, they were the same that were found in the primary level coursebooks, namely, asking for help and cooperating with others. 


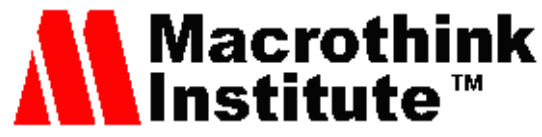

International Journal of Linguistics

ISSN 1948-5425

2020, Vol. 12, No. 2

Given that CLIL refers to a foreign language learning context which shares much of the linguistic issues associated with 'traditional' foreign and second language education (where the language is the actual object of study), we are convinced that the findings cited above may inspire similar research on CLIL textbooks. Furthermore, as remarked in Ball (2018, p. 225), "CLIL has helped us to understand how subject-based discourse is complex in the L1, never mind in an additional language" and, citing Lee (2006), he adds that, for many students, "learning to use language to express mathematical ideas will be similar to learning to speak a foreign language". In many textbooks, the presence of extensive unfamiliar vocabulary, or familiar vocabulary used in a special way, may hinder comprehension; unfamiliar or less-used grammatical structures such as the passive forms may also increase the complexity of textbook language; the discourse organisation of a textbook, if not clear to the reader, may limit understanding (Chamot \& O'Malley, 1994, p. 48). All this puts the lens on the importance of language (and materials) as the first and foremost route to conceptual and procedural learning, which, in other words, means that acquiring adequate competences and awareness in the language of instruction is important, whatever the language used. Explicit instruction of learning strategies, also directed at their transferability to different contexts, should be central therefore to teaching materials.

\subsection{CLIL DIY Materials}

The shortage of commercial CLIL textbooks means that teachers are unable to rely on ready-made teaching materials, which would be a great help especially in the first year(s) of teaching their subject in the foreign language (López-Medina, 2016, p. 164). As stated in Morton (2013, p. 131), "[if] CLIL teachers do not make their own materials, or at least adapt heavily, they are likely to end up with materials that do not meet the linguistic, cognitive or affective needs of their learners at their specific ages and levels of development."

Again, it is to be recalled that we are not here interested in discussing what characteristics CLIL DIY materials have or should have in order to meet CLIL requirements in general (cf., for example, Ball, 2018; Gondova, 2015; Guerrini, 2009, Mehisto, 2012; Moore \& Lorenzo, 2007). Rather, with our focus being learning strategy development, CLIL DIY materials will be considered in relation to the cognitive, metacognitive e socio-affective processes they activate. In a recent study on CLIL implementation at the primary school level in Italy (pupils' ages 6-10), Coonan and Ricci Garotti (2019, p. 76) found that teachers tend to prefer DIY materials for variety and learner involvement. The textbook is generally absent, replaced by a series of different materials which activate diverse learning processes (drawing, observing, reading, writing, etc.). Their study also revealed that strategy instruction was not always included in CLIL lessons (no strategy was activated by 4 out of 15 teachers in the lessons observed) and, when present, it did not always imply overt metacognitive discussion.

The strength underpinning CLIL DIY materials is that they are selected and adapted bearing in mind the characteristics (age, interests, language level, prior knowledge, learning skills etc.) of a specific group of students and of the setting they are in. Thus, while in a textbook students may find content which presupposes prior knowledge that they do not have or that they struggle to recall, in CLIL DIY materials they will not face this problem, as their teacher 
will have made the necessary adaptations (by means of scaffolding techniques such as pre-reading activities) to make the text clear and comprehensible, from both the linguistic and the content point of view. In this sense, in view of promoting efficient learning strategy instruction in a CLIL classroom, it could be argued that CLIL DIY materials might be preferable to commercial textbooks. The research study presented in the next paragraph was designed to verify this intuition.

\section{The Study}

The aim of the present study was to understand to what extent CLIL materials are oriented towards developing learning strategies (cognitive, metacognitive and socio-affective strategies). By means of a qualitative approach, a comparison was made between learning units in commercial CLIL textbooks and DIY materials created by CLIL teachers.

\subsection{Research Questions}

The following research questions were addressed:

1. What types of learning strategies are embedded in CLIL materials targeting primary (pupils' ages 6-10), lower secondary (ages 11-13) and upper secondary school levels (ages 14-18) in Italy?

2. Is there a difference in terms of types and variety of learning strategies present in textbooks and DIY materials at the three school levels?

3. To what extent are learning strategies taught implicitly or explicitly?

\subsection{Sampling}

The CLIL materials investigated (Table 2) were chosen according to the following criteria:

1. specifically addressed to CLIL students, that is, specifically designed for non-native speakers of English;

2. reliable in terms of underpinning CLIL methodology;

3. comparable in terms of duration and subject area: selected materials are learning units lasting from a minimum of 5 to a maximum of 15 teaching hours. Each textbook-DIY material comparison is based on learning units of similar duration (max difference being 5 hours as in the case of an upper secondary school, see Table 2), pertaining to the same subject area (and even topic, when possible), and targeting the same school level (except for the case of Chemistry/Biology units in the upper school, see Table 2). 
Table 2. Characteristics of the sample

\begin{tabular}{|c|c|c|c|}
\hline & Subject area & Units from Textbook & Units from DIY material \\
\hline \multirow{4}{*}{$\begin{array}{l}\text { Primary } \\
\text { school } \\
\text { level }\end{array}$} & Science & $3^{\text {rd }}$ year -7 hours & $3^{\text {rd }}$ year -7 hours \\
\hline & & $\begin{array}{l}\text { Living \& Non-living } \\
\text { things }\end{array}$ & Dinosaurs \\
\hline & Geography & $5^{\text {th }}$ year -9 hours & $5^{\text {th }}$ year -8 hours \\
\hline & & Italy and its regions & $\begin{array}{l}\text { Italy's Identity Card; Veneto } \\
\text { region }\end{array}$ \\
\hline \multirow{4}{*}{$\begin{array}{l}\text { Lower } \\
\text { secondary } \\
\text { school } \\
\text { level } \\
\end{array}$} & Mathematics/ & $1^{\text {st }}$ year -5 hours & $1^{\text {st }}$ year -7 hours \\
\hline & Science & Polygons & The human body \\
\hline & Geography & $1^{\text {st }}$ year -5 hours & $1^{\text {st }}$ year -8 hours \\
\hline & & Maps & Maps \\
\hline \multirow{4}{*}{$\begin{array}{l}\text { Upper } \\
\text { secondary } \\
\text { school } \\
\text { level }\end{array}$} & Chemistry/ & $3^{\text {st }}$ year -8 hours & $5^{\text {st }}$ year -10 hours \\
\hline & Biology & Nutrition & $\begin{array}{l}\text { Fermentation and } \\
\text { biotechnology }\end{array}$ \\
\hline & History/ & $4^{\text {st }}$ year -15 hours & $10^{\text {st }}$ year -15 hours \\
\hline & Philosophy & The British Empire & $\begin{array}{l}\text { Political animals } \\
\text { (Hobbes and Locke) }\end{array}$ \\
\hline
\end{tabular}

The analysed textbooks were either printed by Italian or English publishers; accompanying teacher's books were also considered. The selected DIY materials were authored by Italian CLIL teachers and came with a teacher's guide.

Given the amount of materials available overall, a total of 12 materials is rather limited in number. However, we believe that the selected sample is sufficiently informative since it includes some of the most widely used CLIL textbooks in Italy and covers a diversity of DIY CLIL units designed by different Italian teachers from diverse backgrounds (Note 1).

\subsection{Procedure}

CLIL materials were analysed following Chamot and O’Malley's (1994, pp. 62-63) learning strategy categorization (see Table 1). Each material was analysed so as to identify the different types of embedded metacognitive, cognitive e socio-affective strategies. Each time a strategy was spotted, it was ticked on a checklist. A note was also made as to whether it entailed explicit or implicit instruction. Further notes were taken about the general design of the materials.

\section{Results}

The results of the study are summarized in Tables 3, 4, 5 and 6.

a. Research question 1

As far as regards research question 1, about the types of learning strategies embedded in the CLIL materials, the following results were found. 
Table 3. Types of learning strategies embedded in the CLIL units examined

\begin{tabular}{|c|c|c|}
\hline $\begin{array}{l}\text { Learning } \\
\text { category }\end{array}$ & $\begin{array}{l}\text { Learning strategy } \\
\text { type }\end{array}$ & $\begin{array}{l}\text { N. of CLIL units } \\
\text { integrating learning } \\
\text { strategies }\end{array}$ \\
\hline \multirow{5}{*}{$\begin{array}{l}\text { Metacognitive (total 21) } \\
23.3 \%\end{array}$} & self-management & 7 \\
\hline & organisation & 1 \\
\hline & selective attention & 8 \\
\hline & monitoring & 1 \\
\hline & self-assessment & 4 \\
\hline \multirow{9}{*}{$\begin{array}{l}\text { Cognitive } \\
\text { (total } 57 \text { ) } \\
63.3 \%\end{array}$} & using resources & 7 \\
\hline & grouping & 9 \\
\hline & taking notes & 2 \\
\hline & using prior knowledge & 11 \\
\hline & summarising & 6 \\
\hline & using imagery & 10 \\
\hline & making inferences & 8 \\
\hline & inductions/deductions & 4 \\
\hline & auditory representation & 0 \\
\hline \multirow{3}{*}{$\begin{array}{l}\text { Socio-affective } \\
\text { (total 12) } \\
13 \%\end{array}$} & asking for clarification & 2 \\
\hline & cooperating & 10 \\
\hline & self-talk & 0 \\
\hline \multicolumn{2}{|c|}{ Total of CLIL units examined } & 12 \\
\hline
\end{tabular}

The types of learning strategies embedded in the CLIL materials that appear the most (see Table 3, above) belong to the cognitive strategy category (63\%) and, of these, 'using prior knowledge' is the most frequent (found in 11 out of 12 CLIL units), followed by 'using imagery' (found in 10 out of 12 units), 'grouping' (found in 9 units), 'making inferences (present in 8 units) and 'using resources' (present in 7 units).

This is followed by the metacognitive strategy category (23\%) where 'selective attention' and 'self-management' (detected respectively in 8 and 7 units) appear most frequently. With reference to the latter, this was done mostly by making learning objectives clear to the students. The fact of sharing expected outcomes with the students is considered to be a primary condition for activating and guiding self-regulated learning and learner autonomy. When learners are aware of what the lesson will be about and why they are doing a task, they will likely be more ready to engage in more conscious and reflected learning. Coherently, after being made aware of expected learning objectives, the students should be asked to exercise further metacognitive strategies, like organising the sequences to accomplish the learning task, monitoring their performance and self-assessing what has been done. Remarkably, the teaching units we analysed did not follow these steps, apart from one case (Chemistry unit in upper secondary school textbook) where learning objectives description was followed by both monitoring and self-assessment activities. In the other cases, there was no evidence of a really consistent strategy instruction: in two cases, students were not 


\section{Macrothink}

International Journal of Linguistics

ISSN 1948-5425

2020, Vol. 12, No. 2

engaged in further metacognitive strategies except for self-assessment (Maths DIY unit, primary school level) and organization (Geography textbook unit, upper secondary school); in the remaining two cases (Geography textbook unit, lower secondary school and Philosophy DIY unit, upper secondary school) no additional metacognitive processes were activated.

The socio-affective strategy category (13\%) is promoted transversally across school levels through the strategy of 'cooperating' with peers' (found in 10 units).

The strategies found to be least present are 'organization' and 'monitoring' (both from the metacognitive category), 'taking notes' (the cognitive category) and 'asking for clarification' (the socio-affective category).

No occurrence is spotted of either 'auditory representation' (cognitive) or 'self-talk' (socio affective).

Table 4. Learning strategies occurrences according to the different school levels

\begin{tabular}{|c|c|c|c|c|}
\hline $\begin{array}{l}\text { Learning } \\
\text { strategy } \\
\text { category }\end{array}$ & $\begin{array}{l}\text { Learning strategy } \\
\text { type }\end{array}$ & $\begin{array}{l}\text { Primary } \\
\text { school }\end{array}$ & $\begin{array}{l}\text { Lower } \\
\text { Secondary } \\
\text { school }\end{array}$ & $\begin{array}{l}\text { Upper } \\
\text { Secondary } \\
\text { school }\end{array}$ \\
\hline \multirow{5}{*}{ Metacognitive } & self-management & $2(2 *)$ & $1(1 *)$ & $4(2 *)$ \\
\hline & organisation & 0 & 1 & 0 \\
\hline & selective attention & 1 & 3 & 4 \\
\hline & monitoring & 0 & 0 & 1 \\
\hline & self-assessment & 1 & 2 & 1 \\
\hline \multirow{9}{*}{ Cognitive } & using resources & 2 & 2 & 3 \\
\hline & grouping & 4 & 4 & 1 \\
\hline & taking notes & 0 & 0 & 2 \\
\hline & $\begin{array}{l}\text { using } \\
\text { knowledge }\end{array}$ & 4 & 3 & 4 \\
\hline & summarising & 1 & 2 & 3 \\
\hline & using imagery & 3 & 3 & 4 \\
\hline & making inferences & 4 & 2 & 2 \\
\hline & inductions/deductions & 0 & 1 & 3 \\
\hline & $\begin{array}{l}\text { auditory } \\
\text { representation }\end{array}$ & 0 & 0 & 0 \\
\hline \multirow{3}{*}{ Socio-affective } & $\begin{array}{l}\text { asking } \\
\text { clarification }\end{array}$ & 0 & 0 & 2 \\
\hline & cooperating & 2 & 4 & 4 \\
\hline & self-talk & 0 & 0 & 0 \\
\hline \multicolumn{2}{|c|}{ Total of CLIL units examined (n.12) } & 4 & 4 & 4 \\
\hline
\end{tabular}

$\left(n^{*}\right)$ Number of cases were learning objectives were declared 


\section{Macrothink}

International Journal of Linguistics

ISSN 1948-5425

2020, Vol. 12, No. 2

Comparing strategy occurrences according to the different school levels (Table 4, above), the following is noted: as to 'selective attention' (metacognitive) and 'making deduction/induction' (cognitive) strategies, the higher the school level, the higher their promotion. Quite the opposite seems to happen with 'grouping' (cognitive strategy): this is ever present in the primary and lower secondary school level materials but almost absent in the upper secondary school level units. A further point to make is that learning objectives were made explicit in only 5 out of the 12 CLIL units (see $n^{*}$ in Table 4). As said, the explicitation of learning objectives plays an important role in the activation of metacognitive strategies.

b. Research question 2

To answer research question 2 about possible differences between learning strategies present in the textbooks and DIY materials at all three school levels, data shows that the strategy types present are almost always the same and no meaningful disparity is apparent.

Table 5. Quantity of learning strategies in CLIL textbook units versus DIY CLIL units

\begin{tabular}{lll}
\hline & $\begin{array}{l}\text { Textbooks } \\
\text { units }\end{array}$ & $\begin{array}{l}\text { DIY } \\
\text { units }\end{array}$ \\
\hline Primary school & 10 & 14 \\
\hline Lower secondary school & 16 & 12 \\
\hline Upper secondary school & 21 & 17 \\
\hline
\end{tabular}

As to variety of learning strategies present in a single unit (Table 5, above), it is not possible to identify a major trend, apart from noticing that at the primary school level there is evidence of a wider range of strategies proposed in DIY materials compared to the textbooks (14 strategy types against 10, respectively), while at lower and upper school levels the picture changes (16 types of strategy present in lower secondary school level textbooks' units against 12 in DIY materials, and 21 types in upper secondary school textbooks against 17 in counterpart DIY units).

c. Research question 3

With reference to research question 3 concerning the extent to which strategies are taught implicitly and explicitly, in only one case do teaching materials make strategy instruction explicit: in a CLIL DIY unit of science for primary school pupils where a listening activity was introduced by an explicit explanation of the strategy by naming it and specifying its aim ("You may use 'selective attention' to listening to this video. 'Selective attention' means that you have to concentrate on specific information. You don't have to understand the whole text"). 
Table 6. Implicit versus explicit learning strategy instruction

\begin{tabular}{|c|c|c|c|}
\hline $\begin{array}{l}\text { Learning strategy } \\
\text { category }\end{array}$ & $\begin{array}{l}\text { Learning strategy } \\
\text { type }\end{array}$ & $\begin{array}{ll}\text { Implict strategy } \\
\text { instrution }\end{array}$ & $\begin{array}{l}\text { Explicit strategy } \\
\text { instrution }\end{array}$ \\
\hline \multirow[t]{5}{*}{ Metacognitive } & self-management & 7 & 0 \\
\hline & organisation & 1 & 0 \\
\hline & selective attention & 7 & 1 \\
\hline & monitoring & 1 & 0 \\
\hline & self-assessment & 4 & 0 \\
\hline \multirow[t]{9}{*}{ Cognitive } & using resources & 7 & 0 \\
\hline & grouping & 9 & 0 \\
\hline & taking notes & 2 & 0 \\
\hline & $\begin{array}{l}\text { using prior } \\
\text { knowledge }\end{array}$ & 11 & 0 \\
\hline & summarising & 6 & 0 \\
\hline & using imagery & 10 & 0 \\
\hline & making inferences & 8 & 0 \\
\hline & inductions/deductions & 4 & 0 \\
\hline & $\begin{array}{l}\text { auditory } \\
\text { representation }\end{array}$ & 0 & 0 \\
\hline \multirow[t]{3}{*}{ Socio-affective } & $\begin{array}{ll}\text { asking } & \text { for } \\
\text { clarification } & \\
\end{array}$ & 2 & 0 \\
\hline & cooperating & 10 & 0 \\
\hline & self-talk & 0 & 0 \\
\hline
\end{tabular}

\section{Discussion}

Results so far lead us to surmise that the learning strategies embedded in CLIL materials are similar to those found in the context of second and foreign language learning as discussed in previous paragraphs of this contribution. Moreover, the high frequency of group activities in the CLIL materials (evident in the frequent presence of the cooperating socio-affective strategy) indicates that the key role of interaction and "pushed" output (Swain, 1993, p. 160) in fostering deep thinking has been taken on board in CLIL also. Yet, some learning strategies - like taking notes and using auditory representation to help process auditory memory - still appear to be underdeveloped. It is evident that taking notes should be included in a CLIL strategy repertoire as early as possible. Content-subject language competence is first of all textual competence and some form of writing is required from the very beginning of schooling (filling in a grid, a map, writing definitions, or taking notes.). Taking notes is a means that students have to organize their learning and personalise what is learnt as the process entails "i. inferring meaning ('making inferences'), ii. summarising the most important information ('summarising'); and iii. identifying the key words that carry the meaning ('selective attention') (Menegale, 2019a, p. 84). Another similarity between second/foreign language learning and CLIL regarding learning strategy instruction is the poor attention given to the socio-affective strategies, such as asking for clarification and self-talk. 


\section{Mll Macrothink}

International Journal of Linguistics

ISSN 1948-5425

2020, Vol. 12, No. 2

The benefit from the use of strategies like private speech, self-talk or quiet rehearsal before speaking is said to be of great help in bilingual programmes (Navés et al., 2002, p. 81) since they reduce anxiety and, at the same time, allow students to become more fluent and accurate when speaking.

It was thought that in DIY materials, as opposed to published materials, there would be a more limited variety of strategies per learning unit as the former are designed for a specific group of students whose previous strategy competence is presumed to be well known by the teacher her/himself. In fact, research on strategy instruction suggests that "teachers should start with a small number of strategies (one or two)", better if supportive of each other, and "permit students to feel success" with them before moving on with other strategies (Chamot \& O' Malley, 1994, p. 65). However, this was not the case. Data showed that the type of strategies in CLIL textbooks and DIY materials is almost the same and, even as to variety in a single CLIL unit, it is not possible to identify relevant differences. It could be assumed therefore that an increase in teacher awareness is needed as to how to wisely integrate strategy instruction into CLIL DIY materials. This would also lead to more extensive explicit instruction in learning strategies throughout the curriculum, which, as data has revealed, is almost totally lacking. Neither CLIL DIY materials (apart from one case) nor textbooks provided opportunities for explicit strategy instruction, which means that students are not being made aware of the processes underpinning the techniques and the mental behavior being trained. Instead, as the literature in the field has shown, explicit instruction makes the difference when dealing with strategy automatisation and transfer to new tasks, in other words, when addressing learning to learn.

\section{Conclusion}

Strategic learning definitely matters (Gu, 2019, p. 22). Furthermore, if "every learning involves language learning or is language learning at the same time and communication, therefore is of overriding importance also in subject learning" (Vollmer, 2008, p. 273), it follows that learning strategy instruction should be carefully and transversally promoted throughout the whole curriculum process.

Though admitting that "[t]he main problem for practising teachers is time, or the lack of it" (Ball, 2018, p. 224), this should not hinder them from dedicating the needed efforts to adapt learning materials and activities. Textbooks are central in many educational contexts, CLIL included, as they support and guide both teachers and learners. However, the textbook "is a tool that becomes significant only when the teacher brings it to life" (López-Medina, 2016, p. 164).

Despite the small sample of CLIL materials considered in this study, the findings match what can be found in the studies by other scholars, namely, that learning strategy instruction cannot be detached from the teachers' awareness of the learning processes involved in a bilingual approach like CLIL and that their intervention is crucial for providing the necessary conditions for learners to be successful. If we accept that CLIL provides a favourable learning context for boosting the development of strategies and for facilitating their transfer across language learning and CLIL settings (Marsh, 2012; Menegale, 2019a; Wolff, 2011, 
2019), special attention should be directed at how to support teachers in enabling all this to happen. Therefore, increasing their knowledge of the CLIL strategy repertoire needed by their students to face the high cognitive challenge in CLIL not only will allow them to make an informed selection of materials to use, whether they are taken from textbooks or are self-made, but will also provide them with awareness as to how to plan and embed explicit learning strategy instruction across the whole (CLIL) curriculum.

\section{References}

Ball, P. (2018). Innovations and Challenges in CLIL Materials Design. Theory Into Practice, 57(3), 222-231. https://doi.org/10.1080/00405841.2018.1484036

Banegas, D. L. (2012). CLIL teacher development: Challenges and experiences. Latin American Journal of Content \& Language Integrated Learning, 5(1), 46-56. https://doi.org/10.5294/laclil.2012.5.1.4

Banegas, D. L. (2017). Teacher-developed materials for CLIL: Frameworks, sources, and activities. The Asian EFL Journal Quarterly, 19(3), 31-48.

Bovellan, E. (2014). Teachers' Beliefs about Learning and Language as reflected in Their Views of Teaching Materials for Content and Language Integrated Learning (CLIL). Jyvaskyla: Centre for Applied Language Studies, University of Jyväskylä.

Bonnet, A. (2012). Language, content and interaction: How to make CLIL classrooms work. In D. Marsh, \& O. Meyer (Eds.), Quality interfaces: Examining evidence \& exploring solutions in CLIL (pp. 175-190). Eichstaett: Eichstaett Academic Press.

Brown, A. L., Bransford, J. D., Ferrara, R. A., \& Campione, J. C. (1983). Learning, remembering, and understanding. In P. H. Mussen (Ed.), Handbook of Child Psychology (Vol. 3, pp. 77-166). https://doi.org/10.4324/9781315211985-5

Butler, D. (2002). Individualizing Instruction in Self-Regulated Learning. Theory Into Practice, 41(2), 81-92. https://doi.org/10.1207/s15430421tip4102_4

Castellano Risco, I. (2019). Understanding the Selection of Vocabulary Learning Strategies: The Impact of the Language Teaching Approach. Journal of English Studies, 17, 75-101. https://doi.org/10.18172/jes.3779

Chamot, A. U., \& O' Malley, J. M. (1994). The CALLA Handbook: Implementing the Cognitive Academic Language Learning Approach. Reading, MA: Addison-Wesley.

Clegg, J. (2007). Analysing the language demands of lessons taught in a second language. In F. Lorenzo, S. Casal Madinabeitia, V. de Alba Quiñones, \& P. Moore (Eds.), Models and Practice in CLIL (Monographic issue, 1, pp. 113-128). Revista Española de Lingüistica Aplicada.

Cohen, A. D., \& Macaro, E. (2007). Language Learner Strategies: Thirty Years of Research and Practice. Oxford, UK: Oxford University Press. 


\section{I Macrothink}

International Journal of Linguistics ISSN 1948-5425 2020, Vol. 12, No. 2

Coonan, C. M. (2007). Insider views of the CLIL class through teacher self-observation introspection. International Journal of Bilingual Education and Bilingualism, 10, 625-646. https://doi.org/10.2167/beb463.0

Coonan, C. M. (2012). Affect and motivation in CLIL. In D. Marsh, \& O. Meyer (Eds.), Quality Interfaces: Examining Evidence and Exploring Solutions in CLIL (pp. 174-189). Eichstätt, Germany: Eichstätt Academic Press.

Coonan, C. M., \& Ricci Garotti, F. (2019). Uno studio qualitativo. In D. Wolff, \& S. Virdia (Eds.), Il CLIL nella scuola primaria. Una ricerca quanti-qualitativa nel contesto trentino (pp. 69-103). Trento, Italy: IPRASE.

Coyle, D. (2005). CLIL: Planning tools for teachers. Nottingham, UK: University of Nottingham.

Elridge, J., Neufeld, S., \& Hancioğlu, N. (2010). Towards a Lexical Framework for CLIL. International CLIL Research Journal, 1(3), 88-103.

García Mayo, M. P., \& Lázaro Ibarrola, A. (2015). Do children negotiate for meaning in task-based interaction? Evidence from CLIL and EFL settings. System, 54, 40-54. https://doi.org/10.1016/j.system.2014.12.001

Gondoavá, D. (2015). Selecting, adapting and creating CLIL materials. In S. Pokrivcáková (Ed.), CLIL in Foreign Language Education (pp. 151-163). Nitra, SK: Constantine the Philosopher University. https://doi.org/10.17846/CLIL.2015.153-163

Gu, P. Y. (2019). Approaches to learning strategy instruction. In A. U. Chamot, \& V. Harris (Eds.), Learning Strategy Instruction in the Language Classroom. Issues and Implementation (pp. 22-37). Bristol, UK: Multilingual Matters. https://doi.org/10.21832/9781788923415-008

Guerrini, M. (2009). CLIL materials as scaffolds to learning. In D. Marsh, P. Mehisto, D. Wolff, R. Aliaga, T. Asikainen, M. J. Frigols, \& G. Langé (Eds.), CLIL practice: Perspectives from the field (pp. 74-78). Jyväskylä, Finland: University of Jyväskylä.

Harris, V. (2019). Diversity and integration in language learning strategy instruction. In A. U. Chamot, \& V. Harris (Eds.), Learning Strategy Instruction in the Language Classroom. Issues and Implementation (pp. 38-52). Bristol, UK: Multilingual Matters. https://doi.org/10.21832/9781788923415-009

Harris, V., Ingvadottir, H., Jones, B., Neuburg, R., Palos, I., \& Schindler, I. (2001). Helping Learners Learn: Exploring Strategy Instruction in Language Classrooms across Europe. Graz, Germany: European Centre for Modern Languages.

López-Medina, B. (2016). Developing a CLIL textbook evaluation checklist. LACLIL, 9(1), 159-173. https://doi.org/10.5294/laclil.2016.9.1.7

Macaro, E. (2018). English medium instruction: Content and language in policy and practice. Oxford, UK: Oxford University Press. 
Macaro, E., Briggs Baffoe-Djan, J., Heath, R., di Sabato, B., Hughes, B., Cuccurullo, D., ... Bier, A. (2019). Transition from Secondary school CLIL to EMI at University: Initial evidence from research in Italy. ELT Research Papers, 19(7), 1-31.

Marsh, D. (2012). Content an Language Integrated Learning (CLIL). A Development Trajectory. Cordoba: Servicio de Publicaciones Universidad de Córdoba.

Martín del Pozo, M. A., \& Rascón Estébanez, D. (2015). Textbooks for Content and Language Integrated Learning: policy, market and appropriate didactics?. Foro de Educación, 13(18), 123-141. https://doi.org/10.14516/fde.2015.013.018.007

Martínez-Adrián, M., Gallardo-del-Puerto, F., \& Basterrechea, M. (2019). On Self-Reported Use of Communication Strategies by CLIL Learners in Primary Education. Language Teaching Research, 23(1), 39-57. https://doi.org/10.1177/1362168817722054

Mehisto, P. (2008). CLIL Counterweights: Recognising and decreasing disjuncture in CLIL. International CLIL Research Journal, 1(1), 93-119.

Mehisto, P. (2012). Criteria for producing CLLIL learning material. Encuentro, 21, 15-33.

Menegale, M. (2018). A study on learner autonomy in content and language integrated learning classrooms. Rassegna Italiana di Linguistica Applicata, 1, 83-96.

Menegale, M. (2019a). Learning strategy instruction in content and language integrated learning programs. In A. U. Chamot, \& V. Harris (Eds.), Learning Strategy Instruction in the Language Classroom, Issues and Implementation (pp. 81-106). Bristol, UK: Multilingual Matters. https://doi.org/10.21832/9781788923415-012

Menegale, M. (2019b). A study on knowledge transfer between in and out-of-school language learning. In M. Menegale (Ed.), Autonomy in language learning: Getting learners actively involved (pp. 274-306). Hong Kong: Candlin \& Mynard.

Möller, V. (2017). Language Acquisition in CLIL and Non-CLIL Settings. Amsterdam: John Benjamins Publishing.

Moore, P. (2011). Collaborative interaction in turn-taking: A comparative study of European bilingual (CLIL) and mainstream (MS) foreign language learners in early secondary education. International Journal of Bilingual Education and Bilingualism, 14(5), 531-549. https://doi.org/10.1080/13670050.2010.537741

Moore, P., \& Lorenzo, F. (2007). Adapting authentic materials for CLIL classrooms: An empirical study. Vienna English Working Papers, 16(3), 28-36.

Morton, T. (2013). Critically Evaluating Materials for CLIL: Practitioners' Practices and Perspectives. In J. Gray (Ed.), Critical Perspectives on Language Teaching Materials (pp. 111-136). Basingstoke, UK: Palgrave Macmillan.

Navés, T. (2009). Effective content and language integrated learning (CLIL) programmes. In Y. Ruiz de Zarobe, \& R. M. Jiménez Catalán (Eds.), Content and Language Integrated 
Learning: Evidence from research in Europe (pp. 22-40). Bristol, UK: Multilingual Matters. https://doi.org/10.21832/9781847691675-005

Navés, T., Muñoz, C., \& Pavesi, M. (2002). Second language acquisition for CLIL: Module 2. In G. Langé, \& P. Bertaux (Eds.), TIE-CLIL Professional Development Course. Milano, Italy: Direzione Regionale Lombardia.

O’Malley, J. M., \& Chamot, A. U. (1990). Learning Strategies in Second Language Acquisition. Cambridge, UK: Cambridge University Press. https://doi.org/10.1017/CBO9781139524490

Oxford, R. L. (2011). Teaching and researching language learning strategies. Harlow, UK: Pearson Education.

Papaja, K. (2014). The role of metacognitive awareness in reading comprehension of CLIL learners. In A. Łyda, \& K. Szcześniak (Eds.), Awareness in Action: The Role of Consciousness in Language Acquisition (pp. 194-206). Berlin, Germany: Springer International Publishing. https://doi.org/10.1007/978-3-319-00461-7_13

Psaltou-Joycey, A. (2014). Language learning SI: The English language course books in the Greek state school. Journal of Applied Linguistics, 29, 6-23.

Psaltou-Joycey, A. (2019). Guidelines and materials for integrating language learning strategy instruction into the language lesson. In A. U. Chamot, \& V. Harris (Eds.), Learning Strategy Instruction in the Language Classroom. Issues and Implementation (pp.171-183). Bristol, UK: Multilingual Matters. https://doi.org/10.21832/9781788923415-019

Psaltou-Joycey, A., Mattheoudakis, M., \& Alexiou, T. (2014). Language learning strategies in CLIL and non-CLIL classes: Which strategies do young learners claim they use?. In A. Psaltou-Joycey, M. Mattheoudakis, \& E. Agathopoulou (Eds.), Cross-Curricular Approaches to Language Education (pp. 305-322). Cambridge, UK: Cambridge Scholars Publishing.

Ruiz de Zarobe, Y., \& Zenotz, V. (2015). Reading strategies and CLIL: the effect of training in formal instruction. Language Learning Journal, 43(3), 1-15. https://doi.org/10.1080/09571736.2015.1053284

Ruiz de Zarobe, Y., \& Zenotz, V. (2018). Learning strategies in CLIL classrooms: how does strategy instruction affect reading competence over time?. International Journal of Bilingual Education and Bilingualism, 319-331. https://doi.org/10.1080/13670050.2017.1391745

Swain, M. (1993). The Output Hypothesis: Just speaking and writing aren't enough. The Canadian Modern Language Review, 50, 158-165. https://doi.org/10.3138/cmlr.50.1.158

Tomlinson, B. (2012). Materials development for language learning and teaching. Language Teaching, 45(2), 143-179. https://doi.org/10.1017/S0261444811000528 


\section{Macrothink}

International Journal of Linguistics

ISSN 1948-5425

2020, Vol. 12, No. 2

Van de Craen, P., Mondt, K., Allain, L., \& Gao, Y. (2007). Why and how CLIL works. An outline for a CLIL theory. In U. Smit, \& C. Dalton-Puffer (Eds.), Current Research on CLIL 2, VIEWS (Vienna English Working Papers) (Vol. 16, No. 3, pp. 70-78).

Vollmer, J. (2008). Constructing tasks for content and language integrated learning and assessment. In J. Eckerth, \& S. Siekmann (Eds.), Task-Based Language Learning and Teaching. Theoretical, Methodological, and Pedagogical Perspectives (pp. 227-290). Frankfurt; Germany: Peter Lang.

Wolff, D. (2010). Developing curricula for CLIL: Issues and problems. In B. O’ Rourke, \& L. Carson (Eds.), Language learner autonomy, Policy, curriculum, classroom, A festchrift in honour of David Little (pp. 211-222). Bern, Switzerland: Peter Lang.

Wolff, D. (2011). CLIL and learner autonomy: relating two educational concepts. Education et Sociétés Plurilingues, 30, 69-80.

Wolff, D. (2019). Breve rassegna dei principali studi empirici. In D. Wolff, \& S. Virdia (Eds.), Il CLIL nella scuola primaria. Una ricerca quanti-qualitativa nel contesto trentino (pp. 11-18). Trento, Italy: IPRASE.

Yang, W. (2018). The Deployment of English Learning Strategies in the CLIL Approach: A Comparison Study of Taiwan and Hong Kong Tertiary Level Contexts. ESP Today, 6(1), 44-64. https://doi.org/10.18485/esptoday.2018.6.1.3

\section{Note}

Note 1. The textbooks considered for analysis are published by Erickson, Loescher, Richmond and Zanichelli. The DIY materials selected were authored by either single or teams of teachers trained in CLIL.

\section{Copyrights}

Copyright for this article is retained by the author(s), with first publication rights granted to the journal.

This is an open-access article distributed under the terms and conditions of the Creative Commons Attribution license (http://creativecommons.org/licenses/by/4.0/) 